\title{
STRATY TERYTORIALNE DIECEZJI WŁOCŁAWSKIEJ W NASTĘPSTWIE BULLI CYRKUMSKRYPCYJNEJ VIXDUM POLONIAE UNITAS Z 1925 R.
}

Najpierw należy wyjaśnić pojęcia. Kiedy mówimy diecezja włocławska, prawidłowo wiążemy ją z siedzibą, a raczej stolicą diecezji w tym mieście. Jednak na przestrzeni swoich prawie tysiącletnich dziejów, nosiła ona różne nazwy nawiązujące do obszarów, jakie tworzyły jej okręg. Wprawdzie często nazywano ją diecezją kujawską, ale do czasów, kiedy była ona z siedzibą w Kruszwicy, a było to już prawie tysiąc lat temu, nie sięgamy. Jednak od 1123 roku Włocławek jest stolicą diecezji, którą w pierwszym okresie nazywano często diecezją kujawską i pomorska, bo te dzielnice ją tworzyły. Kiedy na ziemiach polskich w 1818 roku zaborcy wymusili na Stolicy Apostolskiej nowe rozgraniczenie diecezji, jej terytorium znacznie się zmieniło, bowiem w zamian za odpadłe archidiakonaty kruszwicki i wielki archidiakonat pomorski, otrzymała niejako w spadku po archidiecezji gnieźnieńskiej duży okręg ciągnący się do Kalisza. Piotrkowa Trybunalskiego, a nawet kilka parafii

* Ks. dr hab. Witold Kujawski, kapłan diecezji włocławskiej, jest dyrektorem Archiwum Diecezjalnego we Włocławku. 
w rejonie Częstochowy, należące poprzednio do diecezji krakowskiej. Ale i wówczas, chociaż z polecenia władzy zaborczej biskupi mieli polecenie rezydować w stolicy guberni, Kaliszu, Włocławek pozostał stolicą tej diecezji, nazywanej kaliską, włocławską, a najczęściej kujawsko-kaliską. Zatem $\mathrm{w}$ artykule niniejszym będzie chodziło o to, co odeszło od tej diecezji kujawsko-kaliskiej w 1925 roku. Wówczas Stolica Apostolska w bulli Vixdum Poloniae Unitas użyła nazwy włocławska na naszą diecezję․

Nie ma wątpliwości, że podział ziem polskich na diecezje podczas rozbiorów nie spełniał potrzeb Kościoła. Odzyskanie prze Polskę niepodległości w 1918 roku postawiło przed Kościołem w Polsce ważne zadanie uporządkowania granic diecezji polskich. Ostatnia regulacja miała miejsce w 1818 bullą Ex imposita Nobis, odnoszaca się do zaboru rosyjskiego, czyli tzw. Królestwa Polskiego, i drugą z 1821 roku znaną jako bulla De salute animarum, odnoszącą się do Prus i zaboru pruskiego. Były one wymuszone przez państwa zaborcze. Nie brano wówczas pod uwagę względów duszpasterskich, ale uwarunkowania polityczne. Dotyczyło to także diecezji włocławskiej, która w okresie rozbiorowym nosiła nazwę diecezji kujawsko-kaliskiej. Jej granice były z różnych względów niepraktyczne, sama zaś diecezja zbyt duża i rozciągająca się ponad 300 kilometrów z północy na południe. Oczywista więc była konieczność zmiany granic, a także oddania pewnych terytoriów dla innych diecezji ${ }^{2}$. Nie ma jednak potrzeby przedstawiania całego procesu przygotowania zmian i ich przeprowadzenia. W niniejszym artykule chcemy się zając tym, co oddała diecezja kujawsko-kaliska, którą odtąd nazywa się diecezją włocławską. Ta zresztą nazwa diecezji została jedyną właściwą w bulli z 1925 roku

Kiedy więc podczas pierwszej wojny światowej zarysowała się nadzieja, że Polska może odzyskać swoją suwerenność, zaczęto myśleć o koniecznej korekcie granic diecezji polskich, a nawet o konieczności powołania nowych diecezji. Podyktowane to było dużym rozwojem demograficznym niektórych okręgów, zwłaszcza tam, gdzie w XIX wieku silnie rozwijał się przemysł. Może pewnym zwróceniem uwagi na konieczność nowych diecezji było swego rodzaju przecięcie archidiecezji warszawskiej w 1915 roku przez front wojenny, co spowodowało wyznaczenie dla

${ }^{1}$ Syntetyczne omówienie nazewnictwa diecezji i jej okręgu por. S. Librowski, Wizytacje diecezji włocławskiej, wstęp ogólny, "Archiwa, Biblioteki i Muzea Kościelne", t. 8,1964 , s. $13-44$.

${ }^{2}$ Sprawy diecezji kujawsko-kaliskiej, w tym także sytuacja w chwili odzyskania niepodległości przez Polskę, zostały omówione w pracy: W. Kujawski, Diecezja kujawsko-kaliska. Opracowanie historyczno-źródtoznazcze, Włocławek 2011. 
odciętej od stolicy archidiecezji administratora apostolskiego w osobie biskupa kujawsko-kaliskiego Stanisława Zdzitowieckiego ${ }^{3}$, który swoim wikariuszem generalnym uczynił proboszcza parafii św. Józefa w Łodzi, Henryka Przeździeckiego ${ }^{4}$. Okaże się, że nawet ordynariusz archidiecezji warszawskiej będzie zwolennikiem, aby w Łodzi, która stała się w XIX wieku znacznym miastem, powstała samodzielna diecezja ${ }^{5}$, co zostanie niebawem urzeczywistnione.

Prace nad projektami rozpoczęli biskupi polscy najpierw pod kierownictwem prymasa Królestwa Polskiego, Aleksandra Kakowskiego ${ }^{6}$, a gdy już Polska wybuchła, pracami kierował arcybiskup gnieźnieński Edmund Dalbor ${ }^{7}$, rozumiejąc swoje dziedzictwo prymasów Polski ${ }^{8}$.

Główną przyczynę powodującą utratę pewnych i to bardzo dużych okręgów byłej diecezji kujawsko-kaliskiej stanowił rozwój okręgów w rejonie Częstochowy i Łodzi. Co do tej ostatniej, to już 10 grudnia 1920 roku została ona powołana bullą Christi Domini, qui sese bonum pastorem, początkowo kierowana przez arcybiskupa Aleksandra Kakowskiego, jako administratora apostolskiego, ale 11 kwietnia 1921 roku pierwszym biskupem łódzkim został mianowany proboszcz parafii św. Stanisława Kostki w Łodzi, Wincenty Tymieniecki ${ }^{9}$. W 1925 roku, gdy podejmowano decyzje o nowych granicach diecezji było oczywiste, że diecezja łódzka powinna zostać powiększona. Częstochowa zaś z podwójnej racji, mianowicie jako miejsce sanktuarium narodowego na Jasnej Górze pretendowała, aby stać się siedzibą biskupstwa, a drugim atutem był niezwykły rozwój miasta

${ }^{3}$ Biogram tego biskupa por.: W. Frątczak, Zdzitowiecki Stanistaw Kazimierz (1854-1927) ordynariusz włoctawski, opiekun robotników, w: Wtoctawski stownik biograficzny, t. 1, Włocławek 2004, s. 186-188.

${ }^{4}$ Biogram Henryka Ignacego Przeździeckiego, przyszłego biskupa podlaskiego por. P. Nitecki, Biskupi Kościoła w Polsce w latach 965-1999, Warszawa 2000, kol. 364.

${ }^{5}$ M. Budziarek, M. Wrzeszcz, Eódzka diecezja, w: Encyklopedia katolicka, t. 11, Lublin 2006, kol. 555.

${ }^{6}$ Biogram tego arcybiskupa i kardynała por. J. Mandziuk, Kakowski Aleksander, kard., w: Encyklopedia katolicka, t. 8, Lublin 2000, kol. 346-347.

7 Biogram por. M. Banaszak, Dalbor Edmund arcybiskup, kardynat, w: Encyklopedia katolicka, t. 3, Lublin 1985, kol. 976-977.

${ }^{8}$ B. Kumor, Granice metropolii i diecezji polskich (968-1939), „Archiwa, Biblioteki Muzea Kościelne, t. 21, 1970, s. 352-359; omówienie tych spraw zobacz też: H. E. Wyczawski, Organizacja kościelna, w: Historia Kościoła w Polsce, red. B. Kumor i Z. Obertyński, t. II, cz. 2, Poznań-Warszawa 1979, s. 22-44.

${ }_{9}^{9}$ M. Budziarek, M. Wrzeszcz, dz. cyt., kol. 555-558, gdzie podano bibliografię dotyczącą tej diecezji; B. Kumor, dz. cyt., s. 390-393; biogram biskupa Tymienieckiego, por., P. Nitecki, dz. cyt., kol. 457.. 
i okręgu, ze względu na rozwijający się przemysł. I to wzięto pod uwagę tak przy opracowywaniu projektu rozgraniczenia, jak i w samej bulli cyrkumskrypcyjnej.

Bulla papieska Vixdum Poloniae Unitas, określająca nowe granice metropolii i diecezji polskich, mogła zostać wydana po ostatecznym ustaleniu granic Rzeczypospolitej Polskiej i zawarciu przez nią konkordatu ze Stolicą Apostolską. Podpisanie konkordatu nastąpiło 10 lutego 1925 roku $^{10}$. W ślad za tym mogło nastąpić w dniu 28 października 1925 roku ogłoszenie decyzji Stolicy Apostolskiej o nowym rozgraniczeniu diecezji polskich, a także o nowych metropoliach i diecezjach ${ }^{11}$. Diecezja włocławska wracała do dawnej, historycznej metropolii gnieźnieńskiej. Została jednak znacznie okrojona co do swojego obszaru, na rzecz niedawno erygowanej diecezji w Łodzi oraz nowej w Częstochowie ${ }^{12}$, a także, na wyraźną prośbę biskupa płockiego, Antoniego Juliana Nowowiejskiego ${ }^{13}$, do tej diecezji wróciła parafia w Duninowie, w latach 1800-1925 będąca w diecezji włocławskiej ${ }^{14}$.

Stan diecezji włocławskiej w nowym kształcie, bo takiej użyto nazwy, podała bulla, postanawiając, że diecezja włocławska będzie się składała z następujących dekanatów: włocławskiego z wyjątkiem parafii Duninów, brzeskiego, chodeckiego, nieszawskiego, piotrkowskiego (Piotrków Kujawski), radziejowskiego, kaliskiego, koźmineckiego, stawiszyńskiego, stawskiego, izbickiego, kolskiego, konińskiego, tuliszkowskiego, sieradzkiego, szadkowksiego, warckiego, złoczewskiego, słupeckiego,

${ }^{10}$ Tekst konkordatu por. Archiwum Diecezjalne we Włocławku, Akta Kurii Diecezjalnej we Włocławku, og I, 2, k. 3ns.

${ }^{11}$ Tekst tej bulli por. Ditionis polonicae de nova dioecesium latini ritus circupscriptione. Pius Episcous Servus Servorum Dei, ad perpetuam rei memoriam, [po polsku - Konstytucja apostolska Vix dum Poloniae Unitas o nowem rozgraniczeniu diecezji w Polsce], „Kronika Diecezji Kujawsko-Kaliskiej”, t. 20, 1926, s. 1-9; Bulla Vix dum Poloniae Unitas, "Ateneum Kapłańskie", t. 16: 1923-1925, s. 73-79. Słowo Vixdum raz pisano oddzielnie, raz łącznie. $\mathrm{Z}$ racji wystawienia tej bulli zdaje się, że zainteresowane diecezje, a może wszystkie, ponosiły pewne koszta. Znamy zobowiązanie nowej diecezji w Częstochowie, na którą przypadało 5500 lirów włoskich. Administrator Apostolski tej diecezji, biskup Zdzitowiecki, w odezwie do duchowieństwa tej diecezji ustalił, jak należy rozłożyć składkę na wszystkich księży - por. ADWł., AKDWł., og. I, 2, k. 126

${ }^{12}$ J. Związek, Częstochowska diecezja, w: Encyklopedia katolicka, t. 3, Lublin 1985, kol. 851-852, gdzie podano najważniejsze pozycje tej diecezji poświęcone.

${ }^{13}$ Biogram tego arcybiskupa i błogosławionego por. W. Graczyk, Nowowiejski Antoni Julian, bt. arcybp, w: Encyklopedia katolicka, t. 14, Lublin 2010, kol. 81-82.

${ }^{14}$ B. Kumor, Granice diecezji i metropolii, s. 394. 
zagórowskiego, tureckiego, uniejowskiego z wyłączeniem parafii w Bałdrzychowie i Wartkowicach oraz kłodawskiego (ten ostatni z diecezji łódzkiej). Ponadto do diecezji należeć miały parafie z diecezji płockiej: Bobrowniki, Chełmica Wielka, Ciechocin, Czernikowo, Dobrzejewice, Działyń, Grochowalsk, Karnkowo, Kikół, Lipno, Łążyn, Mazowsze, Nowogród, Osiek nad Wisłą, Ostrowite, Szpetal Górny, Sumin, Wielgie, Wola i Zaduszniki ${ }^{15}$.

Patrząc na ten wykaz dekanatów i wspominając ich wykaz sprzed 1925 roku, widzimy wielkość oddanych terenów. Dokładniej możemy się zorientować, dokąd odeszły dekanaty, gdy zobaczymy, z jakich dekanatów miały się składać diecezja w Łodzi i w Częstochowie.

I tak diecezja łódzka otrzymała dekanaty: łódzki, zgierski, brzeziński, łęczycki, tomaszowski, bełchatowski z wyłączeniem parafii Grzymalina Wola, piotrkowski (Piotrków Trybunalski), tuszyński, łaski, pabianicki, widawski, poddębicki, ozorkowski i parafie Bałdrzychów i Wartkowice ${ }^{16}$. Natomiast nowa diecezja częstochowska objęła swoimi granicami dekanaty: częstochowski, kłobucki, mstowski, brzeźnicki, gidelski z wyłączeniem parafii Koniecpol (ta parafia już wcześniej została włączona do diecezji kieleckiej), radomskowski, gorzkowicki, będziński, zawierciański, żarecki, sosnowiecki, wieluński, wieruszowski i parafia Grzymalina Wola ${ }^{17}$. Ponadto bulla ta postanawiała wyraźnie, że duchowni parafii przyłączonych do nowych diecezji tym samym są do nich kanonicznie włączeni oraz należało przekazać akta parafii i personalne stosownie do nowej przynależności diecezjalnej ${ }^{18}$. W wykazie powyższym podano także dekanaty $\mathrm{z}$ innych diecezji, a wchodzące do diecezji częstochowskiej.

Komentator diecezjalny do opublikowanego tekstu bulli z jednej strony wyraził pogląd, że zmiany te mogły nastąpić dzięki opatrznościowemu rezultatowi wojny światowej pozwalającemu na wskrzeszenie Polski, a z drugiej przypomniał, że jedną trzecią swojego terytorium diecezja oddała na rzecz innych diecezji ${ }^{19}$.

Te postanowienia spowodowały kolejne kroki prawne już na terenie zainteresowanych diecezji.

${ }^{15}$ Bulla Vix dum Poloniae Unitas, s. 74, Konstytucja apostolska, s. 3.

${ }^{16}$ Konstytucja apostolska, s. 4.

17 Tamże, s. 8.

18 Tamże.

19 Tekst nie podpisany, jako komentarz redakcji do tekstu bulli, „Kronika Diecezji Kujawsko-Kaliskiej", t. 20, 1926, s. 9. 
Wykonawcą bulli był ówczesny nuncjusz apostolski, Lorenzo Lauri ${ }^{20}$ i w związku z tym wysłał odpowiednie polecenia do biskupów diecezji. Ponieważ utworzona była nowa diecezja Częstochowie, nuncjusz, powołując się na uprawnienia nadane mu przez Stolicę Apostolską, mianował 16 listopada 1925 roku biskupa Stanisława Zdzitowieckiego administratorem apostolskim tej diecezji ${ }^{21}$. Biskup Zdzitowiecki, pewnie z uwagi na swoje lata, a także, aby zapewnić należytą opiekę nad diecezją częstochowską, mianował tam swoim wikariuszem generalnym biskupa sufragana, Władysława Krynickiego $^{22}$, z pełnią władzy, o czym powiadomił 21 listopada arcybiskupa nuncjusza ${ }^{23}$. Może spodziewano się, że biskup Krynicki, który rezydował wówczas w Częstochowie, pozostanie pierwszym biskupem nowej diecezji. Okazało się jednak, że ta nominacja nie rokowała nadziei na dłuższy czas, bowiem już 29 listopada nuncjatura informowała, że został naznaczony ordynariuszem częstochowskim ks. Teodor Kubina, stąd biskup Zdzitowiecki ma władzę do chwili przejęcia diecezji przez nowego ordynariusza ${ }^{24}$.

Niebawem też, bo 27 stycznia 1926 roku biskup Zdzitowiecki powiadomił duchowieństwo diecezji częstochowskiej, że pierwszym biskupem ordynariuszem diecezji został mianowany ksiądz dr Teodor Kubina ${ }^{25}$, dotychczasowy proboszcz parafii Najświętszej Marii Panny w Katowicach i że konsekracja nowego biskupa odbędzie się 2 lutego na Jasnej Górze. Wezwał też do modlitwy o siłę i Boże błogosławieństwo dla niego ${ }^{26}$.

Jak to już wyżej nadmieniono, najwięcej parafii odeszło $\mathrm{z}$ dotychczasowej diecezji kujawsko-kaliskiej do diecezji częstochowskiej. Stąd

${ }^{20}$ Biogram tego arcybiskupa, potem kardynała por.: Stanisław Wilk, Lauri Lorenzo, kard., w: Encyklopedia katolicka, t. 10, Lublin 2004, kol. 575.

${ }^{21}$ Archiwum Diecezjalne we Włocławku, Akta Kurii Diecezjalnej we Włocławku, og. I, 2, k. 102. Dalej cytuję: ADWł., AKDWł., og. I, 2.

${ }^{22}$ Biogram tego biskupa por. J. Pietrzykowski, Krynicki Wtadystaw, biskup, w: Encyklopedia katolicka, t. 9, Lublin 2002, kol. 1397.

${ }^{23}$ ADWł., AKDWł., og. I, 2, k. 106.

${ }^{24}$ Tamże, k. 112

${ }^{25}$ Biogram tego biskupa por. J. Związek, Kubina Teodor, biskup, w: Encyklopedia katolicka, t. 10, kol. 136-137.

${ }^{26}$ ADWł., AKDWł., og. I, 2, k. 128-129. Na marginesie tej wiadomości rodzi się pytanie. Schematyzmy diecezjalne wydaje się zazwyczaj na początku roku, którego dotyczą. Pierwszym schematyzmem diecezji częstochowskiej jest ten na 1926 roku. Dlaczego więc podaje on, że biskupem częstochowskim jest już Teodor Kubina. Widać więc, że wydawnictwo to w pewien sposób uprzedziło wydarzenie, które miało się odbyć dopiero 2 lutego, a mianowicie konsekrację biskupią pierwszego ordynariusza częstochowskiego. Por.: Schematismus universi enerabilis cleri saecularis et regularis dioecesis Częstochoviensis pro Anno Domini 1926, s. 5. 
i przygotowanie akt parafialnych i akt personalnych duchowieństwa które odeszło, wymagało zapewne więcej czasu. A może i dlatego się nie spieszono, bo tymczasowo terenami tymi zarządzał biskup włocławski. Może komunikacja pomiędzy kuriami we Włocławku i Częstochowie nie była też najlepsza, ponieważ 22 marca 1926 roku Kuria Diecezjalna Włocławska pierwsza wysłała zawiadomienie, że akta te są gotowe do odebrania ${ }^{27}$. Chodziło o akta odłączonych parafii i o akta osobowe duchowieństwa. Ci co znają los dokumentów dziewiętnastowiecznych znajdujących się w urzędzie dawnego Konsystorza Generalnego Włocławskiego, a od zmian kodeksowych w 1818 roku w Kurii Diecezjalnej wiedzą, że akta te nie były zbyt obfite, ponieważ prawie wszystkie uległy zniszczeniu w następstwie pożaru pałacu biskupiego i sąsiadującej z nim siedziby tego urzędu. Powiadomiona Kuria częstochowska, zorganizowana zapewne jeszcze przez wikariusza generalnego biskupa Krynickiego, w dniu 26 marca prosi o łaskawe przysłanie tej dokumentacji. Podpisał tę prośbę ówczesny wikariusz generalny diecezji częstochowskiej, ks. Franciszek Marecki ${ }^{28}$. Pewnie jednak chodziło o to, żeby akta te przesłać pocztą. Przygotowane akta, wraz ze spisem, wysłano w dniu 7 kwietnia. Sporządzono wykaz parafii i księży, odtąd do diecezji w Częstochowie przechodzących ${ }^{29}$, a 8 kwietnia powiadomiono listownie Kurie częstochowską, że wszystko wysłano ${ }^{30}$. Spis ten uwidocznił ile parafii i księży przeszło do tej diecezji. Ponieważ pomiędzy stanem duchowieństwa dekanatów odłączanych według stanu na początek 1926 roku, a wspomnianym wykazem zachodzą różnice, znaczy to, że nastąpiło wiele zmian, jakie normalnie są dokonywane w diecezji, a może też niektórzy kapłani nie chcieli do nowej diecezji przechodzić. Dlatego zasadnym wydaje się podać wykaz parafii i duchowieństwa według wyżej wspomnianego spisu $^{31}$. Przedstawimy to za pomocą tabeli, podając przy tej okazji liczbę wiernych, opierając się na danych ze schematyzmu diecezji włocławskiej, czyli kaliskiej z 1925 roku.

\footnotetext{
${ }^{27}$ ADWł., AKDWł., og. I, 2, k. 131.

${ }^{28}$ Tamże, k. 132.

${ }^{29}$ Tamże, k. 134-136.

${ }^{30}$ Tamże, k. 133.

${ }^{31}$ Tamże, k. 134-136.
} 
Tabela 1

\begin{tabular}{|c|c|c|c|c|}
\hline Lp. & Parafia & Kapłan & Stanowisko & $\begin{array}{c}\text { Liczba } \\
\text { wiernych }^{32}\end{array}$ \\
\hline 1 & 2 & 3 & 4 & 5 \\
\hline \multicolumn{5}{|c|}{ Dekanat częstochowski } \\
\hline 1 & $\begin{array}{l}\text { Częstochowa } \\
\text { Par. św. Rodziny }\end{array}$ & $\begin{array}{l}\text { Wróblewski Bolesław } \\
\text { Godziszewski Antoni } \\
\text { Gryglewicz Franciszek }\end{array}$ & $\begin{array}{l}\text { dziekan } \\
\text { i proboszcz. } \\
\text { wikariusz } \\
\text { wikariusz }\end{array}$ & 29500 \\
\hline 2 & $\begin{array}{l}\text { Częstochowa } \\
\text { Par. św. Zygmunta }\end{array}$ & $\begin{array}{l}\text { Marecki Franciszek } \\
\text { Giebartowski Władysław } \\
\text { Józef Patrzyk }\end{array}$ & $\begin{array}{l}\text { proboszcz } \\
\text { wikariusz } \\
\text { wikariusz } \\
\end{array}$ & 25930 \\
\hline \multirow[t]{3}{*}{3} & $\begin{array}{l}\text { Częstochowa } \\
\text { Par. św. Barbary }\end{array}$ & $\begin{array}{l}\text { Nassalski Marian } \\
\text { Sewerynek Antoni } \\
\text { Czajka Stanisław }\end{array}$ & $\begin{array}{l}\text { proboszcz } \\
\text { wikariusz } \\
\text { wikariusz }\end{array}$ & 16850 \\
\hline & Częstochówka ${ }^{33}$ & $\begin{array}{l}\text { Waśkiewicz Piotr } \\
\text { Mrotek Edmund }\end{array}$ & $\begin{array}{l}\text { proboszcz } \\
\text { wikariusz }\end{array}$ & - \\
\hline & $\begin{array}{l}\text { Inni kapłani } \\
\text { mieszkający } \\
\text { i pracujący } \\
\text { w Częstochowie }\end{array}$ & $\begin{array}{l}\text { Ciesielski Michał } \\
\text { Smagaj Jan } \\
\text { Mondry Wojciech } \\
\text { Grochowski Antoni } \\
\text { Makowski Karol } \\
\text { Mieszczański Stefan } \\
\text { Tomaszewski Jan } \\
\text { Sobański Piotr } \\
\text { Wesołowski Władysław } \\
\text { Szewczyk Józef }\end{array}$ & & \\
\hline 4 & Biała & Smolarkiewicz Władysław & proboszcz & 3017 \\
\hline 5 & Blachownia & Kubowicz Marian & proboszcz & 4265 \\
\hline 6 & Kalej & Bilski Stanisław & proboszcz & - \\
\hline 7 & Kamienica Polska & Sędzimir Zygmunt & proboszcz & 2250 \\
\hline 8 & Konopiska & Kiełbasiński Władysław & proboszcz & 6075 \\
\hline 9 & Poczesna & Gawlikowski Klemens & proboszcz & 4920 \\
\hline 10 & Raków & Niedźwiecki Stefan & proboszcz & 6047 \\
\hline 11 & Starcza & Kucharski Wacław & proboszcz & 2200 \\
\hline \multicolumn{5}{|c|}{ Dekanat gidelski } \\
\hline 12 & Gidle & Maciaszek Faustyn & \begin{tabular}{|l|} 
dziekan \\
i proboszcz
\end{tabular} & 4700 \\
\hline
\end{tabular}

${ }^{32}$ Liczbę wiernych podaje się wg schematyzmu: Catalogus ecclesiarum et utriusque cleri tam saecularis quam regularis dioecesis Wladislaviensis seu Calissiensis pro Anno Domini $1925 r$.

${ }^{33}$ Nie ma tej parafii w schematyzmie z 1925 roku. Kapłani wymienieni byli wśród nauczycieli religii w Częstochowie. Ks. Mrotek w 1925 roku. występuje jeszcze jako alumn Seminarium. 
Cd. tabeli 1

\begin{tabular}{|c|c|c|c|c|}
\hline 1 & 2 & 3 & 4 & 5 \\
\hline 13 & Borzykowa & $\begin{array}{l}\text { Majewski Stanisław } \\
\text { Rosiński Władysław }\end{array}$ & $\begin{array}{l}\text { proboszcz } \\
\text { wikariusz }\end{array}$ & 5550 \\
\hline 14 & Cielętniki & Marciniak Wincenty & proboszcz & 1700 \\
\hline 15 & Dąbrowa Zielona & Jatowtt Alojzy & proboszcz & 4000 \\
\hline 16 & Garnek & Znamierowski Kazimierz & proboszcz & 2734 \\
\hline 17 & Kłomnice & Kossowski Roman & proboszcz & 5460 \\
\hline 18 & Maluszyn & Glass Wincenty & proboszcz & 3900 \\
\hline 19 & Pławno & Krawczyński jan & proboszcz & 2456 \\
\hline 20 & Przyrów & Stanisław Grzywak & proboszcz & 5100 \\
\hline 21 & Soborzyce & -34 & - & 1400 \\
\hline 22 & Zawada & Krajewski Adam & proboszcz & 1354 \\
\hline 23 & Żytno & Dominiak Stefan & proboszcz & 3680 \\
\hline \multicolumn{5}{|c|}{ Dekanat gorzkowicki } \\
\hline 24 & Gorzkowice & $\begin{array}{l}\text { Nowicki Romuald } \\
\text { Dudek Ludwik }\end{array}$ & $\begin{array}{l}\text { proboszcz } \\
\text { wikariusz }\end{array}$ & 5509 \\
\hline 25 & Bęczkowice & Nuszkiewicz Stanisław & proboszcz & 4000 \\
\hline 26 & Bogdanów & $\begin{array}{l}\text { Muszyński Ludwik } \\
\text { Piekieliński J,ozef }\end{array}$ & $\begin{array}{l}\text { proboszcz } \\
\text { wikariusz }\end{array}$ & 9000 \\
\hline 27 & Gomulice & Wojtasik Władysław & proboszcz & 2920 \\
\hline 28 & Kamieńsk & $\begin{array}{l}\text { Michalski Bartłomiej } \\
\text { Urban Stanisław }\end{array}$ & $\begin{array}{l}\text { proboszcz } \\
\text { wikariusz }\end{array}$ & 7865 \\
\hline 29 & Lubień & Krawiecki Jan & proboszcz & 1800 \\
\hline 30 & Mierzyn & Christof Antoni & proboszcz & 3450 \\
\hline 31 & Ręczno & Kalinowski Franciszek & proboszcz & 5000 \\
\hline 32 & Rozprza & $\begin{array}{l}\text { Szymanowski Bolesław } \\
\text { Prawda Jan }\end{array}$ & $\begin{array}{l}\text { dziekan } \\
\text { i proboszcz } \\
\text { wikariusz }\end{array}$ & 8473 \\
\hline \multicolumn{5}{|c|}{ Dekanat brzeźnicki } \\
\hline 33 & Brzeźnica & $\begin{array}{l}\text { Jankowski Teofil } \\
\text { Lipski Stefan }\end{array}$ & $\begin{array}{l}\text { dziekan } \\
\text { i proboszcz } \\
\text { wikariusz } \\
\end{array}$ & 6055 \\
\hline 34 & Dworszowice & Pabich Stanisław & proboszcz & 1019 \\
\hline 35 & Działoszyn & $\begin{array}{l}\text { Charliński Ignacy } \\
\text { Szyca Jan }\end{array}$ & $\begin{array}{l}\text { proboszcz } \\
\text { wikariusz }\end{array}$ & 7900 \\
\hline 36 & Jedlno & Maderski Emmanuel & proboszcz & 1605 \\
\hline 37 & Kiełczygłów & Wróbel Antoni & proboszcz & 3000 \\
\hline 38 & Lgota & Kowalski Wawrzyniec & proboszcz & 3600 \\
\hline
\end{tabular}

${ }^{34}$ Nie podano przy tej parafii duchownego. 
Cd. tabeli 1

\begin{tabular}{|c|c|c|c|c|}
\hline 1 & 2 & 3 & 4 & 5 \\
\hline 39 & Makowiska & Zaborski Józef & proboszcz & 3120 \\
\hline 40 & Pajęczno & $\begin{array}{l}\text { Chwiłowicz Aureliusz } \\
\text { Janic Konstanty }\end{array}$ & $\begin{array}{l}\text { proboszcz } \\
\text { wikariusz }\end{array}$ & 7000 \\
\hline 41 & Rząśnia & $\begin{array}{l}\text { Kokowski Wacław } \\
\text { Dąbrowski Stanisław }\end{array}$ & $\begin{array}{l}\text { proboszcz } \\
\text { wikariusz }\end{array}$ & 8049 \\
\hline 42 & Siemkowice & Peche Tadeusz & proboszcz & 6840 \\
\hline 43 & Sulmierzyce & Cwilong Zenon & proboszcz & 6000 \\
\hline 44 & Wiewiec & Strzelecki Jan & proboszcz & 3712 \\
\hline 45 & Kleszczów & Michałowski Józef & proboszcz & 2457 \\
\hline \multicolumn{5}{|c|}{ Dekanat rodomskowski } \\
\hline 46 & Radomsko & $\begin{array}{l}\text { Jankowski Marian } \\
\text { Bielawski Aleksander } \\
\text { Dyja Edward } \\
\text { Kasprzak Bogumił } \\
\text { Grabowski Wawrzyniec }\end{array}$ & $\begin{array}{l}\text { dziekan } \\
\text { i proboszcz } \\
\text { wikariusz } \\
\text { wikariusz } \\
\text { prefekt } \\
\text { prefekt }\end{array}$ & 24356 \\
\hline 47 & Bąkowa Góra & Secomski Kazimierz & proboszcz & 3133 \\
\hline 48 & Chełmno & Zaremba Leon & proboszcz & 5800 \\
\hline 49 & Dmenin & Kozakowski Józef & proboszcz & 2500 \\
\hline 50 & Dobryszyce & Witczak Aleksander & proboszcz & 1786 \\
\hline 51 & Kobiele Wielkie & Drejem Zygmunt & proboszcz & 3383 \\
\hline 52 & Kodrąb & Śnieżewski Bronisław & proboszcz & 4000 \\
\hline 53 & Krępa & Zieliński Roman & proboszcz & 911 \\
\hline 54 & Kruszyna & Metler Bonawentura & proboszcz & 5000 \\
\hline 55 & Niedośpielin & Gostyński Aleksander & proboszcz & 1700 \\
\hline 56 & Radziechowice $^{35}$ & Zawadzki Wincenty & proboszcz & - \\
\hline 57 & Rzejowice & Szczotkowski Wacław & proboszcz & 2362 \\
\hline 58 & Wielgomłyny & Lubecki Ignacy & proboszcz & 5600 \\
\hline \multicolumn{5}{|c|}{ Dekanat mstowski } \\
\hline 59 & Mstów & $\begin{array}{l}\text { Maniewski Michał } \\
\text { Halama Alojzy }\end{array}$ & $\begin{array}{l}\text { proboszcz } \\
\text { wikariusz }\end{array}$ & 8450 \\
\hline 60 & Borowno & $\begin{array}{l}\text { Patorski Jan } \\
\text { Niederman Alfons }\end{array}$ & $\begin{array}{l}\text { proboszcz } \\
\text { wikariusz }\end{array}$ & 7500 \\
\hline 61 & Cykarzew & Pawłowski Ignacy & proboszcz & 2500 \\
\hline 62 & Mykanów & Kowalewski Leonard & proboszcz & 2800 \\
\hline
\end{tabular}

${ }^{35}$ Nie ma takiej parafii w $1925 \mathrm{r}$. ani w poprzednich. Może wprowadzić to zamieszanie co do liczby parafii. Ksiądz Zawadzki Wincenty był w 1925 roku wikariuszem w Radomsku. Zapewne w 1925 roku utworzono nową parafię przy kaplicy św. Rozalii w Radziechowicach wyjętej z parafii Radomsko. 
Cd. tabeli 1

\begin{tabular}{|c|c|c|c|c|}
\hline 1 & 2 & 3 & 4 & 5 \\
\hline 63 & Rędziny & Łabęda Jan & $\begin{array}{l}\text { dziekan } \\
\text { i proboszcz }\end{array}$ & 5650 \\
\hline 64 & Żóraw & Marjankowski Ignacy & proboszcz & 3865 \\
\hline \multicolumn{5}{|c|}{ Dekanat kłobucki } \\
\hline 65 & Kłobucko & $\begin{array}{l}\text { Zagrzejewski Antoni } \\
\text { Borek Władysław }\end{array}$ & $\begin{array}{l}\text { proboszcz } \\
\text { wikariusz }\end{array}$ & 9000 \\
\hline 66 & Bór Zapilski & Lubowidzki Mikołaj & proboszcz & 5000 \\
\hline 67 & Danków & Graczykowski Mieczysław & proboszcz & 4600 \\
\hline 68 & Krzepice & $\begin{array}{l}\text { Zawadzki Zygmunt } \\
\text { Wróblewski Michał }\end{array}$ & $\begin{array}{l}\text { dziekan } \\
\text { i proboszcz } \\
\text { wikariusz }\end{array}$ & 5837 \\
\hline 69 & Miedzno & Opasewicz Tomasz & proboszcz & 4228 \\
\hline 70 & Ostrowy & Borek Adam & proboszcz & 2300 \\
\hline 71 & Panki & Mietliński Antoni & proboszcz & 2900 \\
\hline 72 & Parzymiechy & Kobielski Feliks & proboszcz & 3600 \\
\hline 73 & Przystajnia & $\begin{array}{l}\text { Żor Adam } \\
\text { Ogłaza Stanisław }\end{array}$ & $\begin{array}{l}\text { proboszcz } \\
\text { wikariusz }\end{array}$ & 7715 \\
\hline 74 & Staro Krzepice & Bieniasiewicz Franciszek & proboszcz & 3200 \\
\hline 75 & Trusolasy & Siemaszko Władysław & proboszcz & 5960 \\
\hline 76 & Wąsosz & Choroszyński Bolesław & proboszcz & 4160 \\
\hline 77 & Wilkowiecko & Rzykiecki Franciszek & proboszcz & 4000 \\
\hline 78 & Zajczki & Gozdek Adolf & proboszcz & 2524 \\
\hline 79 & Złochowice & Kwinciński Jakub & proboszcz & 1700 \\
\hline \multicolumn{5}{|c|}{ Dekanat wieluński } \\
\hline 80 & Wieluń & $\begin{array}{l}\text { Przygocki Wincenty } \\
\text { Augustynik Piotr } \\
\text { Marekwia Franciszek }\end{array}$ & $\begin{array}{l}\text { dziekan } \\
\text { i proboszcz } \\
\text { prefekt } \\
\text { prefekt } \\
\end{array}$ & 10327 \\
\hline 81 & Biała & Muchański Andrzej & proboszcz & 2500 \\
\hline 82 & Chotów & Czarnecki Wincenty & proboszcz & 3100 \\
\hline 83 & Czarnożyły & Rechciński Ignacy & proboszcz & 5500 \\
\hline 84 & Kadłub & Drojewski Roman & proboszcz & 2000 \\
\hline 85 & Konopnica & Osmelak Jan & proboszcz & 1442 \\
\hline 86 & Krzyworzeka & Dudzik Jan & proboszcz & 1800 \\
\hline 87 & Łyskornia & Gurbiel Stanisław & proboszcz & 2500 \\
\hline 88 & Mierzyce & $\begin{array}{l}\text { Gorzędowski Franciszek } \\
\text { Klarzak Józef }\end{array}$ & $\begin{array}{l}\text { proboszcz } \\
\text { wikariusz }\end{array}$ & 5654 \\
\hline 89 & Ossjaków & $\begin{array}{l}\text { Michnikowski Bolesław } \\
\text { Gołaszewski Stanisław }\end{array}$ & $\begin{array}{l}\text { proboszcz } \\
\text { wikariusz }\end{array}$ & 10268 \\
\hline
\end{tabular}


Cd. tabeli 1

\begin{tabular}{|c|c|c|c|c|}
\hline 1 & 2 & 3 & 4 & 5 \\
\hline 90 & Raczyn & Olejnik Wincenty & proboszcz & 2025 \\
\hline 91 & Ruda & Zmysłowski Antoni & proboszcz & 4100 \\
\hline 92 & Rydlice & Hadaś Emmanuel & proboszcz & 5500 \\
\hline 93 & Wierzchlas & Głogowski Wawrzyniec & proboszcz & 3300 \\
\hline \multicolumn{5}{|c|}{ Dekanat bolesławiecki } \\
\hline 94 & Bolesławec & Wojciechowski Wincenty & \begin{tabular}{|l|} 
dziekan \\
i proboszcz
\end{tabular} & 3100 \\
\hline 95 & Chróścin & Paterek Franciszek & proboszcz & 1000 \\
\hline 96 & Czastary & Wilczyński Władysław & proboszcz & 3700 \\
\hline 97 & Dzietrzkowice & Sukiennicki Stanisłąw & proboszcz & 3721 \\
\hline 98 & Mieleszyn & Kotnowski Bolesław & proboszcz & 1350 \\
\hline 99 & Mokrsko & Orżanowski Wiktor & proboszcz & 3200 \\
\hline 100 & Radostów & Degen Stefan & proboszcz & -36 \\
\hline 101 & Skomlin & Bentkowski Edward & proboszcz & 3587 \\
\hline 102 & Wójcin & Jędryczki Cyryl & proboszcz & 2600 \\
\hline 103 & Żdżary & Jarzębiński Dominik & proboszcz & 2000 \\
\hline \multicolumn{5}{|c|}{ Dekanat praszkowski } \\
\hline 104 & Praszka & $\begin{array}{l}\text { Wtorkiewicz Franciszek } \\
\text { Sawicki Marian }\end{array}$ & $\begin{array}{l}\text { dziekan } \\
\text { i proboszcz } \\
\text { prefekt }\end{array}$ & 9043 \\
\hline 105 & Dzietrzniki & Sikorski Władysław & proboszcz & 3600 \\
\hline 106 & Jaworzno & Wieczorek Stanisław & proboszcz & 2314 \\
\hline 107 & Komorniki & Czok Jan & proboszcz & 1200 \\
\hline 108 & Ożarów & Rychlewski Stanisław & proboszcz & 1590 \\
\hline 109 & Pątnów & Kosielski Antoni & proboszcz & 1650 \\
\hline 110 & Przedmość & Marcinkowski Władysław & proboszcz & 1410 \\
\hline 111 & Rudniki & Berendt Leopold & proboszcz & 3500 \\
\hline 112 & Wierzbie & -37 & - & 1360 \\
\hline 113 & Żytniów & Łogucki Józef & proboszcz & 3800 \\
\hline \multicolumn{5}{|c|}{ Dekanat wieruszowski } \\
\hline 114 & Wieruszów & $\begin{array}{l}\text { Kott Walenty } \\
\text { Eupiński Stanisław } \\
\end{array}$ & $\begin{array}{l}\text { proboszcz } \\
\text { prefekt }\end{array}$ & 6000 \\
\hline 115 & Cieszęcin & Zieliński Hipolit & \begin{tabular}{|l|} 
dziekan \\
i proboszcz
\end{tabular} & 5300 \\
\hline 116 & Czajków & Tarchalski Edmund & proboszcz & 4300 \\
\hline
\end{tabular}

${ }^{36} \mathrm{~W}$ schematyzmie nie ma podanej liczby wiernych.

${ }^{37} \mathrm{Nie}$ podano nazwiska proboszcza. 
Cd. tabeli 1

\begin{tabular}{|c|c|c|c|c|}
\hline 1 & 2 & 3 & 4 & 5 \\
\hline 117 & Kraszewice & Kępski Leon & proboszcz & 4200 \\
\hline 118 & Lututów & $\begin{array}{l}\text { Żeromski Stanisław } \\
\text { Konieczny Julian }\end{array}$ & $\begin{array}{l}\text { proboszcz } \\
\text { prefekt }\end{array}$ & 7000 \\
\hline 119 & Naramice & -38 & - & 1530 \\
\hline 1 & 2 & 3 & 4 & 5 \\
\hline 120 & Ochędzyn & Kłódkowski Wincenty & proboszcz & 1400 \\
\hline 121 & Ostrówek & Gruszewski Józef & proboszcz & 1437 \\
\hline 122 & Sokolniki & Grzmielewski Barnaba & proboszcz & 2100 \\
\hline 123 & Walichnowy & Chrzanowski Wacław & proboszcz & 2800 \\
\hline 124 & Węglewice & Pawłowski Edward & proboszcz & 3188 \\
\hline \multicolumn{5}{|c|}{ Uzupełnienie } \\
\hline 125 & Raków ${ }^{39}$ & $\begin{array}{l}\text { Karczewski Apolinary } \\
\text { Rosso Włodzimierz }\end{array}$ & $\begin{array}{l}\text { prefekt } \\
\text { prefekt }\end{array}$ & \\
\hline 126 & Grzymalina Wola & Hlawsa Leon & proboszcz & 2300 \\
\hline
\end{tabular}

Podsumowując dane z podanej tabeli, dowiadujemy się, że do diecezji częstochowskiej przeszło 126 parafii, 167 kapłanów i 564,768 wiernych

Nieco mniej, ale także znaczącą liczbę parafii, kapłanów i wiernych, diecezja oddała do diecezji w Łodzi.

Biskupi zawiadamiali dziekanów oddawanych dekanatów o decyzji Stolicy Apostolskiej. I tak biskup Zdzitowiecki 21 listopada 1925 roku powiadomił dziekanów z Tuszyna, Łasku, Pabianic, Piotrkowa Trybunalskiego, Bełchatowa i Widawy, że dekanaty te zostały włączone do diecezji łódzkiej i dziekani mają niezwłocznie powiadomić o tym kondekanalnych, aby we wszystkich sprawach zwracali się do Kurii Diecezjalnej w Łodzi ${ }^{40 .}$

Ponieważ w nowej sytuacji należało przekazać do aktualnych Kurii Biskupich dokumentację oddawanych parafii, kuria włocławska powiadomiła biskupa łódzkiego, że są już przygotowywane akta parafii do przekazania ${ }^{41}$.

Wykaz parafii i księży przechodzących do diecezji w Łodzi z Kurii włocławskiej wysłano z Włocławka 30 listopada ${ }^{42}$. Zawierał on następujące akta parafii i księży, ujęte $\mathrm{w}$ formę tabeli $\mathrm{z}$ podaniem liczby wiernych poszczególnych parafii.:

\footnotetext{
${ }^{38}$ Nie podano nazwiska proboszcza.

${ }^{39}$ Por. par Raków nr 10, gdzie podano tylko proboszcza. Tu podano prefektów.

${ }^{40}$ ADWł., AKDWł., og. I, 2, k. 111.

${ }^{41}$ Tamże, k. 107.

${ }^{42}$ Tamże, k 113-114v.
} 
Tabela 2

\begin{tabular}{|c|c|c|c|c|}
\hline Lp. & Parafia & Kapłan & Stanowisko & $\begin{array}{c}\text { Liczba } \\
\text { wiernych }\end{array}$ \\
\hline 1 & 2 & 3 & 4 & 5 \\
\hline \multicolumn{5}{|c|}{ Dekanat piotrkowski (Piotrków Trybunalski) } \\
\hline 1 & $\begin{array}{l}\text { Piotrków } \\
\text { Trybunalski } \\
\text { Par. św. Jakuba }\end{array}$ & $\begin{array}{l}\text { Jasiński Włodzimierz } \\
\text { Siutowicz Józef } \\
\text { Jastrzębski Stefan }\end{array}$ & $\begin{array}{l}\text { dziekan } \\
\text { i proboszcz } \\
\text { wikariusz } \\
\text { wikariusz }\end{array}$ & 13000 \\
\hline 2 & $\begin{array}{l}\text { Piotrków } \\
\text { Trybunalski } \\
\text { Par. św. Jacka }\end{array}$ & $\begin{array}{l}\text { Szabelski Stanisław } \\
\text { Dziuda Józef } \\
\text { Potrzebki Wiktor } \\
\text { Lipiński Eugeniusz } \\
\text { Zając Stanisław } \\
\text { Krzyszkowski Jan } \\
\text { Rutkiewicz Bronisław }\end{array}$ & $\begin{array}{l}\text { proboszcz } \\
\text { wikariusz } \\
\text { Rektor } \\
\text { kościoła } \\
\text { prefekt } \\
\text { prefekt } \\
\text { prefekt } \\
\text { prefekt }\end{array}$ & 14000 \\
\hline 3 & Gomolin & Borowski Roman & proboszcz & 1500 \\
\hline 4 & Milejów & $\begin{array}{l}\text { Jankowski Piotr } \\
\text { Szymański Antoni }\end{array}$ & $\begin{array}{l}\text { proboszcz } \\
\text { wikariusz } \\
\end{array}$ & 5325 \\
\hline 5 & Moszczenica & Kieler Stanisław & proboszcz & 2270 \\
\hline 6 & Sulejów & $\begin{array}{l}\text { Nawrocki Lucjan } \\
\text { Dziwok Wincenty }\end{array}$ & $\begin{array}{l}\text { proboszcz } \\
\text { wikariusz } \\
\end{array}$ & 8356 \\
\hline 7 & Witów & Bronisław Jaskólski & proboszcz & 2456 \\
\hline 8 & Wolbórz & $\begin{array}{l}\text { Pertkiewicz Ignacy } \\
\text { Szamborski Nikodem }\end{array}$ & $\begin{array}{l}\text { proboszcz } \\
\text { wikariusz }\end{array}$ & 13421 \\
\hline \multicolumn{5}{|c|}{ Dekanat bełchatowski } \\
\hline 9 & Bełchatów & $\begin{array}{l}\text { Jeliński Franciszek } \\
\text { Leszczyński Leon }\end{array}$ & $\begin{array}{l}\text { dziekan } \\
\text { i proboszcz } \\
\text { prefekt }\end{array}$ & 4500 \\
\hline 10 & Chabielice & Beliński Michał & proboszcz & 4600 \\
\hline 11 & Drużbice & Raszka Ignacy & proboszcz & 5800 \\
\hline 12 & Grocholice & Goczałkowski Cezary & proboszcz & 5118 \\
\hline 13 & Kaszewice & Załęcki Karol & proboszcz & 3025 \\
\hline 14 & Kociszew & Kaszyca Leon & proboszcz & 2500 \\
\hline 15 & Łobudzice & $\begin{array}{l}\text { Esman Edward } \\
\text { Grodkiewicz Jan }\end{array}$ & $\begin{array}{l}\text { proboszcz } \\
\text { prefekt } \\
\text { i rektor k-ła }\end{array}$ & 5000 \\
\hline 16 & Parzno & Rubaszkiewicz Jan & proboszcz & 6858 \\
\hline 17 & Suchcice & Zagórski Leon & proboszcz & 1677 \\
\hline \multicolumn{5}{|c|}{ Dekanat tuszyński } \\
\hline 18 & Tuszyn & $\begin{array}{l}\text { Pełczyński Józef } \\
\text { Teper Jan }\end{array}$ & $\begin{array}{l}\text { proboszcz } \\
\text { prefekt }\end{array}$ & 8650 \\
\hline 19 & Krzepczów & Stawicki Mikołaj & proboszcz & 4370 \\
\hline
\end{tabular}


Cd. tabeli 2

\begin{tabular}{|c|c|c|c|c|}
\hline 1 & 2 & 3 & 4 & 5 \\
\hline 20 & Srocko & $\begin{array}{l}\text { Kowalski Izydor } \\
\text { Górecki Józef }\end{array}$ & $\begin{array}{l}\text { proboszcz } \\
\text { wikariusz }\end{array}$ & 8250 \\
\hline 21 & Czarnocin & Kąkolewski Feliks & proboszcz & 4500 \\
\hline 22 & Kurowice & Wituski Andrzej & proboszcz & 4540 \\
\hline 23 & Rzgów & $\begin{array}{l}\text { Sieciński Stanisław } \\
\text { Piwnicki Stefan }\end{array}$ & $\begin{array}{l}\text { proboszcz } \\
\text { prefekt }\end{array}$ & 5200 \\
\hline \multicolumn{5}{|c|}{ Dekanat łaski } \\
\hline 24 & Łask & $\begin{array}{l}\text { Kopczyński Edward } \\
\text { Kołodziejski Stefan } \\
\text { Sikorski Wacław }\end{array}$ & $\begin{array}{l}\text { dziekan } \\
\text { i proboszcz } \\
\text { wikariusz } \\
\text { prefekt }\end{array}$ & 7200 \\
\hline 25 & Borszewice & Lewandowicz Mieczysław & proboszcz & 3545 \\
\hline 26 & Buczek & Drzymała Stanisław & proboszcz & 4100 \\
\hline 27 & Dobroń & Cesarz Jan & proboszcz & 3828 \\
\hline 28 & Kwiatkowice & Migasiewicz Tomasz & proboszcz & 2010 \\
\hline 29 & Lutomiersk & Psonka Franciszek & proboszcz & 2850 \\
\hline 30 & Marzenin & $\begin{array}{l}\text { Sawicki Marceli } \\
\text { Nowak Adam }\end{array}$ & $\begin{array}{l}\text { proboszcz } \\
\text { wikariusz }\end{array}$ & 5100 \\
\hline 31 & Mikołajewice & Borowy Henryk & proboszcz & 3120 \\
\hline 32 & Wrzeszczewice & Dzikowski Jan & proboszcz & 1600 \\
\hline \multicolumn{5}{|c|}{ Dekanat pabianicki } \\
\hline 33 & $\begin{array}{l}\text { Pabianice } \\
\text { Par. św. Mateusza }\end{array}$ & $\begin{array}{l}\text { Marecki Stanisław } \\
\text { Kubiś Wojciech }\end{array}$ & $\begin{array}{l}\text { dziekan } \\
\text { i proboszcz } \\
\text { wikariusz }\end{array}$ & 10000 \\
\hline 34 & $\begin{array}{l}\text { Pabianice } \\
\text { Par. N.M.P. - księ- } \\
\text { ży misjonarzy }\end{array}$ & $\begin{array}{l}\text { Szulc Bartłomiej } \\
\text { Olszewka Teodor } \\
\text { Warchoł Franciszek } \\
\text { Gielac Emil } \\
\text { Urban Jan } \\
\text { Musiał Kazimierz } \\
\end{array}$ & $\begin{array}{l}\text { proboszcz } \\
\text { wikariusz } \\
\text { wikariusz } \\
\text { prefekt } \\
\text { prefekt } \\
\text { prefekt }\end{array}$ & 16500 \\
\hline 35 & Dłutów & $\begin{array}{l}\text { Szarecki Andrzej } \\
\text { Strumiłło Antoni }\end{array}$ & $\begin{array}{l}\text { proboszcz } \\
\text { wikariusz }\end{array}$ & 7260 \\
\hline 36 & Górka Pabianicka & Wójcik Feliks & proboszcz & 2800 \\
\hline 37 & Retkinia & Walecki Wacław & proboszcz & 2200 \\
\hline 38 & Ruda Pabianicka & $\begin{array}{l}\text { Połabski Franciszek } \\
\text { Szubiński Stanisław }\end{array}$ & $\begin{array}{l}\text { proboszcz } \\
\text { prefekt }\end{array}$ & 4200 \\
\hline \multicolumn{5}{|c|}{ Dekanat widawski } \\
\hline 39 & Widawa & $\begin{array}{l}\text { Wronowski Zygmunt } \\
\text { Fijałkowski Jan }\end{array}$ & $\begin{array}{l}\text { dziekan } \\
\text { i proboszcz } \\
\text { wikariusz } \\
\end{array}$ & 8960 \\
\hline 40 & Brzyków & Milewski Stefan & proboszcz & 3680 \\
\hline 41 & Grabno & Królikowski Franciszek & proboszcz & 3000 \\
\hline
\end{tabular}


Cd. tabeli 2

\begin{tabular}{|c|l|l|l|c|}
\hline 1 & \multicolumn{1}{|c|}{2} & \multicolumn{1}{c|}{ 3 } & \multicolumn{1}{c|}{5} \\
\hline 42 & Restarzew & Wolski Adam & proboszcz & 4200 \\
\hline 43 & Ruciec & Łaski Gustaw & proboszcz & 2830 \\
\hline 44 & Sędziejowice & Ościk Leon & proboszcz & 2000 \\
\hline 45 & Strońsko & Rylski Stefan & proboszcz & 5600 \\
\hline 46 & Szczerców & Kotlicki Ignacy & proboszcz & 4020 \\
\hline 47 & Wola Więzowa & Krukowski Józef & proboszcz & 2346 \\
\hline 48 & Wygiełzów & Susiecki Adam & proboszcz & 4000 \\
\hline \multicolumn{5}{|c|}{ Parafie należące do dekanatu uniejowskiego } \\
\hline 49 & Bałdrzychów & Dmochowski Aleksander & proboszcz & 2262 \\
\hline 50 & Wartkowice & Nowicki Lucjan & proboszcz & 3125 \\
\hline
\end{tabular}

Podsumowując, przeszło do diecezji w Łodzi 50 parafii, 78 kapłanów i 214174 wiernych

Po odbiór tych akt zgłosił się we Włocławku ks. Jan Fondaliński, kwitując ich odbiór 4 grudnia ${ }^{43}$. Zdaje się, że nie zdołano zgromadzić wszystkich materiałów, skoro 14 grudnia wysłano do ładzi resztę akt osobistych księży ${ }^{44}$. Były to akta ks. Dmochowskiego, Cesarza, Drzymały, Dzikowskiego i Diudy.

Naturalnie przy takich sytuacjach są możliwe pomyłki. I tak pomyłkowo przesłano do ładzi Akta ks. Adama Fijałkowskiego, zamiast akt ks. Jana Fijałkowskiego. Ponieważ zaraz zauważono te pomyłkę, Kuria Łódzka 11 grudnia odsyłając akta pomyłkowo przesłana, prosi i właściwe ${ }^{45}$.

Ale to nie koniec wykazu oddawanych parafii. Parafia Koniecpol już 11 listopada 1925 roku dekretem nuncjusza Apostolskiego została wyłączona z diecezji kujawsko-kaliskiej (włocławskiej) i włączona do diecezji kieleckiej, dlatego 19 marca 1925 roku biskup kielecki Łosiński prosił biskupa włocławskiego o przesłanie akt parafii i akt osobistych proboszcza ${ }^{46}$. Proboszczem w 1925 roku był Dembczyk Sylwan, a parafia liczyła 4000 wiernych ${ }^{47}$.

Jedyną parafią przekazaną diecezji płockiej był Duninów. Akta tej parafii wysłano do płocka 5 grudnia, jednak nie wysłano akt ks. Lisiec-

${ }^{43}$ Tamże, k. 115.

${ }^{44}$ Tamże, k. 121.

${ }^{45}$ Tamże, k. 122-123.

${ }^{46}$ Tamże, k. 108.

${ }^{47}$ Schematyzm diecezji włoctawsko-kaliskiej 1925, s. 43. 
kiego Ignacego tamtejszego proboszcza z uwagi, że ich nie było. Jest to zrozumiałe, bowiem akta personalne księży diecezji spłonęły w pożarze Kurii Biskupiej w 1920 roku. Władza kościelna poleciła, aby kapłani sporządzili dokładny swój życiorys, któryby w części zastąpił zniszczone Akta. Nie wszyscy to polecenia wykonali, a wśród nich i proboszcz duninowski ${ }^{48}$. Parafia ta liczyła 4,130 wiernych

Ogółem więc razem z parafiami Koniecpol i Duninowo, odeszło 178 parafii, 247 księży i 783072 wiernych.

Duchowieństwo diecezji włocławskiej pamiętało o konfratrach, których nowe rozgraniczenie diecezji spowodowało, że znaleźli się poza swoja macierzą, czemu dało wyraz, gdy zgromadzeni na zebraniu dziekanów i delegatów we Włocławku w dniu 13 i 14 kwietnia 1926 roku, wysłali pozdrowienia do tych, co odeszli z diecezji: „Zebrani dziekani i delegaci diecezji włocławskiej przesyłają ukochanym kolegom, z którymi tyle lat wspólnie pracowali, dzielili dole i niedole, najserdeczniejsze bratnie pozdrowienie ${ }^{\prime \prime 4}$.

Jeszcze w czasach po drugiej wojnie światowej były liczne więzy pomiędzy starszymi kapłanami tych trzech diecezji, bo łączyło ich wspomnienie tego samego wychowania seminaryjnego, tych samych nauczycieli i biskupa, który ich święcił.

Na zakończenie, opierając się na innym opracowaniu podpisanego, a będącym w druku, możemy porównać, ile diecezja oddała, a ile utraciła i jaki jest ostateczny bilans.

W 1925 roku oddano diecezjom w Częstochowie i Łodzi 176 parafii oraz po jednej dla Kielc i Płocka, co razem stanowi 178, a otrzymano ich zaledwie $20 \mathrm{z}$ diecezji płockiej i $8 \mathrm{z}$ diecezji, łódzkiej czyli łącznie oddano 150 parafii. Kapłanów odeszło 247, a z diecezji płockiej i łódzkiej otrzymano 31, czyli ubyło ich 216, zaś wiernych, których odeszło 783 072, przybyło tylko 85541 osób, czyli liczba wiernych zmniejszyła się o 697531 osób.

Jest zrozumiałe, że $\mathrm{w}$ rzeczywistości liczba wiernych mogła się nieco różnić, ale nie zmienia to faktu, że diecezja włocławska następstwie bulli Ex imposita nobis uległa znacznemu zmniejszeniu.

${ }^{48}$ ADWł., AKDWł., og. I, 2, k. 116.

${ }^{49}$ Protokót zjazdu księży dziekanów i delegatów diecezji włoctawskiej, odbytego w dniach 13 i 14 kwietnia 1926 r., „Kronika Diecezji Kujawsko-Kaliskiej”, t. 20, 1926, s. 175. 


\section{STRATY TERYTORIALNE DIECEZJI WŁOCŁAWSKIEJ W NASTĘPSTWIE BULLI CYRKUMSKRYPCYJNEJ VIXDUM POLONIAE UNITAS Z $1925 \mathrm{R}$.}

\section{STRESZCZENIE}

Kiedy Polska w 1918 roku odzyskała niepodległość, oczywistym okazała się konieczność przeprowadzenia nowego podziału diecezji polskich, a nawet powiększenia ich liczby przez utworzenie nowych. Dotychczasowy bowiem podział z 1818 roku, ustalony pod naciskiem władz zaborczych, nie brał pod uwagę potrzeb Koscioła. Po wielu naradach biskupów polskich i po zawarciu konkordatu pomiędzy Rzeczypospolitą Polską, a Stolicą Apostolską, ta ostatnia bullą Vixdum Poloniae Unitas z 1925 roku dokonała nowego urządzenia diecezji polskich. Jej postanowienia najbardziej dotyczyły diecezji kujawsko-kaliskiej, teraz nazwanej włocławską. Ponieważ już w 1920 roku powstała diecezja w Łodzi, na samej granicy z diecezją włocławską oraz powołano do istnienia diecezję w Częstochowie, obydwie w 1925 roku przejęły dużą część dotychczasowej diecezji kujawsko-kaliskiej. Tak więc diecezja włocławska w granicach ustalonych wspomnianą bullą uległa znacznemu zmniejszeniu, oddajac około trzeciej części parafii, kapłanów i wiernych.

\section{LE PERDUTE TERITORIALI DELLA DIOCESI DI WŁOCŁAWEK COME LA CONSEQUENZA DELLA BULLA PAPALE VIXDUM POLONIAE UNITAS DA 1925}

\section{RIASSUNTO}

Quando la Polonia nel 1918 ha ricuperato l’indipendenza si è nata subito la necessità della nuova divisione delle diocesi. Dopo la lunga discussione tra i vescovi polacchi e dopo la stipulazione del concordato fra Polonia e la Santa Sede e con la bulla papale Vixdum Poloniae Unitas da 1925, si ha compiuta la nuova ripartizione delle diocesi della Polonia. Due nuove diocesi a Czestochowa ed a Lodź hanno intercettato gran parte della precedente diocesi kujawsko-kaliska. 